\title{
How is Bitcoin Money?
}

\author{
Bjerg, Ole
}

Document Version

Accepted author manuscript

Published in:

Theory, Culture \& Society

DOI:

10.1177/0263276415619015

Publication date:

2016

License

Unspecified

Citation for published version (APA):

Bjerg, O. (2016). How is Bitcoin Money? Theory, Culture \& Society, 33(1), 53-72.

https://doi.org/10.1177/0263276415619015

Link to publication in CBS Research Portal

\section{General rights}

Copyright and moral rights for the publications made accessible in the public portal are retained by the authors and/or other copyright owners and it is a condition of accessing publications that users recognise and abide by the legal requirements associated with these rights.

Take down policy

If you believe that this document breaches copyright please contact us (research.lib@cbs.dk) providing details, and we will remove access to the work immediately and investigate your claim.

Download date: 26. Apr. 2023 


\section{How is Bitcoin Money?}

\section{Ole Bjerg}

Journal article (Post print version)

This article was originally published in Theory, Culture \& Society, Vol 33, Issue 1 ,

Pages 53-72. First published online December 1, 2015.

DOI: 10.1177/0263276415619015

Uploaded to Research@CBS: Januar २016 
How is Bitcoin Money? 
Abstract: Bitcoin is a peer-to-peer electronic payment system that operates as an independent currency. This paper is a philosophical investigation of the ontological constitution of Bitcoin. Using Slavoj Žižek's ontological triad of the real, the symbolic and the imaginary, the paper distinguishes between three ideal typical theories of money: commodity theory, fiat theory, and credit theory. The constitution of Bitcoin is analysed by comparing the currency to each of these ideal types. It is argued that Bitcoin is commodity money without gold, fiat money without a state, and credit money without debt. In conclusion it is suggested that Bitcoin poses an ideological challenge to conventional forms of money in so far as it not only provokes sedimented beliefs about money but also exposes the forms of exploitation, risk and even violence inherent in the existing system of state authorised credit money.

Keywords: Bitcoin, money, Žižek, gold, fiat, credit

Word count: 7,954 
Forbes Magazine declared 2013 to be 'The Year of the Bitcoin' (Christensen 2013). It was the year that Bitcoin evolved from a subcultural phenomenon into a common reference point in mainstream public debate. A tangible expression of the rising popularity of Bitcoin, which was at the same time also a propeller of this popularity, was the price of the currency when traded against more conventional money. An investor who bought $10 \mathrm{BTC}$ at the current price of $\$ 13$ per bitcoin on the $1^{\text {st }}$ of January 2013 would have been able to make $\$ 7,000$, if the investment was realized by the end of the year. So far the peak of the price in Bitcoins was reached in December 2013, when the currency was traded at $\$ 1,242$ for one bitcoin. At the time of writing in 2015 the price has slumped back to about $\$ 250$. The usability of the currency has also increased rapidly and today it is possible to pay in Bicoin for a wide variety of commodities and services from electronics and computer hardware to restaurant meals, legal services, and even college education. The future of Bitcoin is still very uncertain. Proponents believe it is going to be the payment system of the future, while critics argue that it is nothing but a Ponzi scheme soon to collapse (Rosenblum 2014; Trugman 2014).

While this article has no qualified opinion about whether there is still money to be gained by investing in Bitcoin, the fundamental proposition is that there is surely a lot of philosophical value to be redeemed through an engagement with the currency. We seem to living in times of not only financial but even monetary turmoil. Martin Heidegger once remarked that it is only when things are broken 
that they become conspicuous and we actually start reflecting on their being (1927, para. 16). Today our monetary system is if not outright broken then at least functioning in ways that are out of the ordinary. While this situation does indeed produce a series of very unfortunate economic effects and insecurities, it also opens a philosophical window of opportunity for thinking and writing about the very nature and being of money. In the following, we are going to use Bitcoin as a way to leverage our reflection on the nature of money. The article is framed by the question stated in the title: How is Bitcoin money? Working with this question, the article has two aims:

1) to provide a philosophical account of the ontological constitution of Bitcoin, and

2) to question the constitution of conventional money by comparing it to Bitcoin.

(How) Is Bitcoin Money?

A straightforward way of approaching Bitcoin might have been to start with a definition of money and then analyse how Bitcoin fits the bill. This is precisely how the Bank of England has structured it's recent report on digital currencies:

From the perspective of economic theory, whether a digital currency may be considered to be money depends on the extent to which it acts as a store of value, a medium of exchange and a unit of account. (Ali et al. 2014, 276) 
While such analysis of Bitcoin may shed some light on the first aim of our article, it fails to accommodate the second aim as it takes the conventional definition of money as well as the conventional forms of money for granted. In contrast to such a 'perspective of economic theory', we shall be pursuing a philosophical approach that takes as its premise that the very ontological foundation of money is inherently undecidable. We are thus aligned with the position pointedly formulated by Graeber: 'money has no essence. It's not "really" anything; therefore, its nature has always been and presumably always will be a matter of political contention' (Graeber 2011, 372). As demonstrated by Ingham 'the mainstream, or orthodox, tradition of modern economics does not attach much theoretical importance to money' (Ingham 2004, 7). Perhaps not surprisingly, the BoE approach to Bitcoin perfectly represents such orthodox thinking, where the very nature of money is rarely if ever questioned. Asking the question: how is Bitoin money?, we thus deliberately sidestep the much more obvious question: is Bitcoin money? This in turn allows us to explore Bitcoin without first committing to any definite theory of money.

Our analysis of Bitcoinapplies

Slavoj Žižek's distinction between the three different ontological orders, real, symbolic, and imaginary, as an analytical prism through which different dimensions of a money system is examined. ${ }^{\mathrm{i}}$ To the extent that the nature of money is even discussed within the field of economics, we can distil three general theories of the origin and constitution of money: the commodity theory, the chartal theory, and the credit theory of money. The contention here is that neither 
of these theories are capable of providing a coherent and conclusive account of the nature of money, while at the same time each of them captures a dimension of the functioning of money. Hence, we shall in the following be using the commodity theory, the fiat theory and the credit theory of money respectively as a series of ideal types to uncover the ontological constitution of Bitcoin as money. But before we enter into this three stage analysis, we shall be looking into the very mechanics of the Bitcoin system.

How does Bitcoin work?

Bitcoin is a virtual network that allows users to transfer digital coins to each other. Each bitcoin consists of a unique chain of digital signatures that is stored in a digital wallet installed on the user's computer. The wallet generates keys used for sending and receiving coins. A transfer of bitcoins is made as the current owner of the coin uses a private digital key to approve of the addition of the recipient's key to a string of previous transactions. The coin is then transferred and now appears in the recipient's wallet with a recorded history of transactions including the one just recently completed.

Since physical objects can only be in one place at the same time, a physical coin cannot be spent simultaneously on two or more separate transactions. Once the coin is in the hands of the payee, the payer cannot spend the same coin once again. A fundamental property of digital entities is, however, that they are easily copied and multiplied. In other words, digital entities can be in several places at 
the same time. Therefore, digital currencies are faced with the problem of doublespending.

Bitcoin's original solution to the problem of double-spending is what makes it fundamentally different from conventional electronic payment systems and vastly more successful than comparable predecessors (Barber et al. 2012). Rather than instituting a central authority of verification, Bitcoin is organized as a decentralized peer-to-peer network. In brief, the solution to the problem of double-spending is to keep a complete and public record of all transactions in the network. Here is how the enigmatic founder of Bitcoin, Satoshi Nakamoto, reflects on the problem and its solution:

We need a way for the payee to know that the previous owners did not sign any earlier transactions. For our purposes, the earliest transaction is the one that counts, so we don't care about later attempts to doublespend. The only way to confirm the absence of a transaction is to be aware of all transactions. In the mint based model, the mint was aware of all transactions and decided which arrived first. To accomplish this without a trusted party, transactions must be publicly announced ..., and we need a system for participants to agree on a single history of the order in which they were received. (Nakamoto 2008, 2)

A transfer of bitcoin is recorded with a time stamp by the network and bundled together with other transactions to form a so-called block. The block is processed by users making their CPU power available to the network. For reasons to be explained later, different users compete against each other to see who is able to 
process the block faster. When a block of transactions has been processed and verified, it is sealed through an operation that connects it to the previous block and it is now added to the so-called block chain. The block chain constitutes the entire history of payments in the system against which new transactions are checked for double-spending. The block chain is a public ledger of transactions and balances in the system.

A crucial feature of any money system is the way that it allows for new money to enter into the economy. Bitcoin combines the function of money creation with the provision of incentives for users to participate in the maintenance of the system:

By convention, the first transaction in a block is a special transaction that starts a new coin owned by the creator of the block. This adds an incentive for nodes to support the network, and provides a way to initially distribute coins into circulation, since there is no central authority to issue them. The steady addition of a constant of amount of new coins is analogous to gold miners expending resources to add gold to circulation. In our case, it is CPU time and electricity that is expended. (Nakamoto 2008, 4)

We see here how new bitcoins are introduced into circulation as rewards to users that process and verify the transactions of a block. This process is also known as mining. It is, however, not enough to just do the rather simple task of processing and verifying transactions in order to claim the reward. In order to regulate the rate at which new bitcoins are created, Bitcoin also requires miners to 
solve a certain cryptographic puzzle before a block may be sealed. The puzzle can only be solved through trial and error and its level of difficulty is steadily increasing over time in order to match the progress in the development of CPU power. This means that miners' computers have to do a certain amount of 'work' in order to solve a block. On average, a new block is solved every ten minutes. The amount of bitcoins per block offered in reward is also adjusted so that the creation of new bitcoins follows a predetermined asymptotic trajectory approaching a total of 21 million in year 2140, when the creation of new coins is terminated. At the time of writing in 2015, the total amount of bitcoins in circulation is approximately 14 million.

We shall now move on to the philosophical analysis of the cryptocurrency.

\section{Gold Standard without Gold}

The famous quip by Keynes that '[p]ractical men, who believe themselves to be quite exempt from any intellectual influences, are usually slaves of some defunct economist,' nicely captures a certain commonsensical understanding of money that prevails even far into the ranks of established academics (Keynes 1936, 383). This is the understanding that once upon a time money emerged as gold or other precious metals and even if contemporary forms of money have been officially decoupled from such a material base of value, we may still understand money as if it were just another commodity in the economy. The 'defunct economist' that is ultimately responsible for this commodity theory of money is usually identified as Adam Smith as he tells the mythical story of the 
butcher, the brewer and the baker, who figures out a way of advancing from simple barter to a money economy by appropriating precious metals as means of exchange (Smith 1776, 24-25). But also Karl Marx and Carl Menger would count as key sources of this classical theory of money, the influence of which may be traced well into contemporary neo-classical economics (Menger 1892; Ingham 2004, 15-37 for overview).

Historians and anthropologists have pointed out how the commodity theory is an incorrect account of the historical origins of money (Humphrey 1985, 48; Ingham 2000; Hudson 2004; Graeber 2011, 23). The commodity theory fails to recognize the role of the state or another sovereign power in establishing currency as an abstract standard of account and it also fails to understand the relations between debt and money (Ingham 2004, 89-133; Ingham 2006). The importance of this critique is, however, not merely historical. As the commodity theory of money is explicitly or implicitly carried over into contemporary neo-classical economics, these failures to recognize especially the role of banks in the creation of money have significant implications for the conclusions that may or may not be drawn from its analyses (Werner 2005; Keen 2011; Hudson 2012; Jackson and Dyson 2013).

At the same time, the commodity theory should perhaps not be dismissed to hastily. One of the lessons to be learned from the financial crisis of 2007-8 concerns the intricate relation between money and real estate (Bryan and Rafferty 2009). At the peak of the asset bubble leading up to the crisis, mortgage backed securities in the form of CDO's would circulate as highly liquid assets in the 
financial markets. It has been suggested that such financial derivatives are in fact a form of money replicating some of the features of a gold standard (Bryan and Rafferty 2006; Bryan and Rafferty 2012). This point may be pushed even further to say that CDOs constitute a new form of commodity money that is coupled not to a gold standard but rather to some kind of real estate standard.

It is far beyond the scope of this article to settle the ongoing debate about the nature of money and the relation between money and commodities. In fact, the choice of Žižek as our theoretical foundation may be understood as a concession to the undecidability of money as an inherent feature of the phenomenon itself. Paraphrasing Lacan's infamous slogan that 'The woman does not exist', our analytical approach to Bitcoin is underpinned by the following assumption: 'Money does not exist'. This obviously does not mean that there is no actual money in the world but rather that money has no transhistorical essence, which would lend it to a general theoretical definition. Such approach to the study of money also puts us in line with Dodd's recent invitation to '[embrace] all of the various empirical forms of money without lapsing into an arbitrary nominalism' (Dodd 2014, 6). In the following, the commodity theory is thus appropriated purely in an ideal typical fashion to review the curious role of gold in the constitution of Bitcoin.

It is immediately clear that there is no gold or other precious metals backing the value of Bitcoin. Bitcoin is a virtual currency and as such it does not seem to carry any relation to a commodity base guaranteeing its value. At the same time, there are a number of features in the composition of Bitcoin, which makes it 
resemble the idea of money inherent in the commodity theory. Most obviously, the supply of Bitcoin is finite. Even though there are no physical limits to the creation of Bitcoins, the system is designed to terminate the issuance of new Bitcoins in 2140, when the total volume reaches 21 million. The cumbersome process of verifying transactions and solving more and more difficult cryptographic puzzles, in order to earn new bitcoins, mimics the hard work of digging precious metal out of the ground: 'The steady addition of a constant amount of new coins is analogous to gold miners expending resources to add gold to circulation' (Nakamoto 2008, 4). Hence, users doing this work are of course known as 'miners', their software as 'bitcoin miners' and their hardware equipment as 'rigs'. Not only the rhetoric but also the imagery surrounding Bitcoin makes very explicit reference to gold. The website, bitcoin.org, displays an animated video, where bitoins are depicted as golden coins that are chipped out of rock by a small axe. Maurer et al. pointedly coin the concept of 'digital metallism' to capture the way that Bitcoin invokes a self conception of being a form of commodity money (Maurer, Nelms, and Swartz 2013).

Furthermore, Bitcoin seem to be underpinned by an ideological superstructure heavily informed by monetarist and libertarian critiques of the conventional money system (Karlstrøm 2014). Nakamoto himself writes: 'We have proposed a system for electronic transactions without relying on trust.' Conventional forms of money rely on central banks and commercial banks to control the issuance of new money and to perform the clearing and verification required to make transactions. In contrast, Bitcoin does not rely on any central authority to complete these 
functions (Barber et al. 2012). The issuance of new coins is inscribed into the code itself and verification is performed by decentralized miners competing about doing the work most efficiently. The incentive structure of Bitcoin is even set up in a way where potential frauds are in principle going to find it more profitable to spend their CPU power on helping to maintain the system rather than trying to circumvent it. In other words, competition rather than trust keeps the system honest:

The incentive may help encourage nodes to stay honest. If a greedy attacker is able to assemble more CPU power than all the honest nodes, he would have to choose between using it to defraud people by stealing back his payments, or using it to generate new coins. He ought to find it more profitable to play by the rules, such rules that favour him with more new coins than everyone else combined, than to undermine the system and the validity of his own wealth. (Nakamoto 2008, 4)

The decentralized nature of Bitcoin is also reflected in the fact that the software underpinning the system is completely open source (Kostakis and Giotitsas 2014). This makes it relatively easy and completely legitimate to create alternative cryptocurrencies based on the Bitcoin source code. Litecoin, Namecoin and Dogecoin are examples of such competing currencies. We see here traces of Hayek's idea of the denationalisation of money, whereby private agents rather than the government would issue independent currencies, which would then in turn compete against each other in the open market (Hayek 1976). According 
to this logic, the possibility of creating competing cryptocurrencies helps to keep Bitcoin itself in check. If Bitcoin fails to service its users in a reliable, efficient and just way, users may simply revert to another system instead.

Since the functioning of Bitcoin does not rely on central or private banks it cannot be abused by such central authorities. Proponents of money that is backed by a standard of precious metals usually argue that this provides 'soundness' by keeping politicians and bankers honest. Bitcoin principally provides this in a digital form. There is no precious metals underlying Bitcoin but still the currency is a finite resource. Selgin refers to Bitcoin as synthetic commodity money to capture this feature (2014). We can also say that Bitcoin relies on a kind of virtual gold standard. Bitcoin is gold money without gold.

The problem of actual money systems that seem to realize the ideas of the commodity theory by connecting the value of money to gold (or other precious metals), is that they ultimately come up against the paradox that gold is priceless (Bjerg 2014, 96-100). With Žižek, we can understand the commodity theory of money as an effort to found the value of money in the dimension of the real by pointing to the intrinsic value of gold as the ultimate support of the currency. It is crucial to note how Žižek's definition of the real is anything but straightforward and even varies throughout his writings. At some points, the real is located in a positive existence beyond the sphere of symbolization. He defines the real as 'that which resists symbolization' and 'as the rock upon which every attempt at symbolization stumbles' $(1989,69,169)$. At other points, the real is located in a negative existence, i.e. as merely a void or an aporia inherent in the symbolic 
order. Žižek states that: 'the symbolic order itself, is ... barré, crossed-out, by a fundamental impossibility, structured around an impossible/traumatic kernel, around a central lack' $(1989,122)$. This lack is the real.

This seemingly ambivalent definition of the real captures very well the function of gold in relation to money. At first glance, gold seems to provide a foundation of intrinsic value that is not subject to monetary inflation. Yet at the same time, gold also 'resists symbolization'. If gold is the standard against which all other commodities is priced, how do we price gold itself. Gold turns out to be priceless in both meanings of the term. We might go even one step further and question the very value of gold. Perhaps the value of commodity money is not derived from the value of gold but the other way around. The reason why gold is so valuable is not that it incarnates a special form of intrinsic value but rather because it is endowed with this special function in relation to money. It functions as the 'fundamental impossibility' and 'traumatic kernel' around which the symbolic system of money is structured. The impossibility of adequately accounting for the value of gold gives rise to an imaginary fantasy of gold as being endowed with some special form of value beyond the ordinary sphere of use-value (Bjerg 2014, 97).

Once we give up the idea of gold as the embodiment of some form of special value that is beyond the sphere of the symbolic order of money, we can see how Bitcoin is perhaps a more honest form of gold money than conventional forms of money based on an actual gold standard. Bitcoin is based on the same kind of negative ontology that we find in Žižek's thinking. Rather than pretending that the 
money system is structured around some positive entity guaranteeing the value of the entire symbolic order, Bitcoin openly admits to being structured around a pure lack. What makes Bitcoin still resemble commodity money even in the absence of gold is of course the limit on the total amount of coins that may ever come into circulation. Since this limit is ultimately based on the self-imposed law inscribed into the code, it is relevant to review Bitcoin in light of the fiat theory of money.

Fiat Money without a State

The fiat theory of money says that money is ultimately the creation of the state or another sovereign entity. A classic formulation of this theory is found in Georg Friedrich Knapp's The State Theory of Money: 'Money is a creature of law,' and hence ' $[t]$ he soul of currency is not in the material of the pieces, but in the legal ordinances which regulate their use' $(1924,1-2)$. Keynes makes explicit reference to Knapp and indeed much of keynesianist economics is based on the idea of fiat money. More recent formulations of the fiat theory of money are found in Mosler (1997), Wray (1998), and Bell (2000). The idea is that states make money through two simultaneous movements. With one hand, the state produces certain objects that are legally designated as money. With the other hand, the state demands the very same objects as payment of taxes, duties, fines, and other kinds of debt from the citizens to the state. Through this creation of both supply and demand the state initiates the circulation of money in the economy. Since all private economic agents are ultimately going to need state authorized money to pay their debts to 
the state, the demand for this money is soon generalized and it begins to circulate even in ordinary transactions between private agents.

As we have seen, the core aim of Bitcoin is to create a form of money that does not rely on trust in any central authority. In this respect, Bitcoin is radically different from fiat money issued by a state of another sovereign entity. Nevertheless, Bitcoin still shares some characteristics with the idea of money found in the fiat theory. Although actual money systems sometimes combine the model of fiat money with elements from commodity money, for instance by issuing a national paper currency that is backed by a gold standard, ideal typical fiat money are characterised by being devoid of any intrinsic value. Paper money such as for instance the Russian RUB 1,000 note or the Danish DKK 100 note have no significant useful purpose other than their function as a means of payment. They have value only because they are generally accepted by a community of money users. The same goes for Bitcoin. Bitcoin has value as money only in so far as there is a community of users willing to accept Bitcoin in exchange for commodities, services, or other forms of money. Bitcoin does not have any intrinsic value. Another proponent of the fiat theory of money, Georg Simmel, states that 'money is only a claim upon society.' And he explains how: '[m]oney appears, so to speak, as a bill of exchange from which the name of the drawee is lacking' $(1900,176)$. This definition fits very well with the functioning of Bitcoin. Bitcoin is a claim upon the 'society' of users willing to accept Bitcoin.

In Making Money, the role of the state in the functioning of fiat money is explained through Žižek's concept of desire. A crucial point in Žižek's thinking 
about the subject is the idea that desire is always symbolically mediated. This is captured by the Lacanian slogan: '[M]an's desire is the Other's desire' (Lacan 1966, 312). It means that the subject's desire is never just a simple, spontaneous craving for a particular object:

$[\mathrm{M}]$ an's desire is structured by the 'decentred' big Other, the symbolic order: what I desire is predetermined by the big Other, the symbolic space within which I dwell. /.../ [T] he subject desires only in so far as it experiences the Other itself as desiring, as the site of an unfathomable desire, as if an opaque desire is emanating from him or her. (Žižek 2006, 41-2).

In the context of fiat money, the state functions as the big Other. By demanding payment of taxes in the kind of objects legally designated as money, the state expresses a desire for these objects as money. Paraphrasing the above quote, we can say that 'what private agents desire as money is predetermined by the big Other of the state, the sovereign economic space within which they do business.' Now this desire of the big Other is incorporated into private agents in the economy as they begin to use these objects as payments among themselves. Private agents no longer experience their desire for particular objects as money as coming from the state. The desire of the Other is the desire of the economic subject.

Now of course Bitcoin differs from the Russian Ruble, the Danish Krone, or other conventional national currencies by the fact that (so far) there is no state using its sovereignty to demand bitcoins in payment of taxes. The community of 
Bitcoin users is a completely voluntary community. No one is forced to accept Bitcoin as payment and no one is forced to use Bitcoin as payment. In conventional systems of fiat money, the state acts to initiate both supply and demand of the currency but eventually the demand for the currency is generalized and it is used even in peer-to-peer transactions in the economy. I use my Danish Kroner not only to pay my taxes but also to buy my groceries. In contrast, Bitcoin works as fiat money without a state. While Bitcoin is, from a purely technical perspective, a fully functional system, it is still in its preliminary stages in terms of establishing a mature economic community of users. The question of whether and how Bitcoin may evolve into a fully fledged currency has been explored both quantitatively and conceptually (Luther 2013; Luther and White 2014; Kostakis and Giotitsas 2014). Karlstrøm conceptualizes this as a problem of the 'social embeddedness' of Bitcoin (Karlstrøm 2014). Within the theoretical framework of the current paper, the challenge is how to create a general desire for bitcoins as money without an actual institution to play the role of the big Other and act as a catalyst for this desire. Perhaps we can refer to Bitcoin as a form of post-fiat money. We have seen how Bitcoin requires no trust in a central authority. In turn, the issue of trust is wholly decentralized in so far as the value of Bitcoin ultimately relies on the users' trust that other users are going to accept the currency in future payments for goods, services and the settlement of debt. In this sense, Bitcoin as post-fiat money is the concrete manifestation of the Lacanian slogan: 'The big Other doesn't exist.' 
Even in the absence of states collecting taxes in Bitcoin, the amount of merchants accepting the currency as payment is rapidly increasing. Still, only few merchants accept Bitcoin exclusively. You can choose to pay in Bitcoin but you might as well just pay in conventional currencies. A notable exception to this rule is the Silk Road website, which is an online market place for a variety of goods but with a primary focus on drugs and other illegal substances (Barratt 2012). The site was in operation between 2011 and 2013, when it was closed by the FBI, but a new and improved version is reported to be up and running again under the name Silk Road 2.0 (Greenberg 2013). Given the illicit nature of the transactions performed through the Silk Road and similar sites, anonymity is a core issue and Bitcoin is thus the only means of payment used on the site (Meiklejohn et al. 2013). A 2012 study provided a rough estimate that Silk Road-related trades constituted between $4.5 \%$ and $9 \%$ of all trades on exchanges where Bitcoin is traded for other conventional currencies (Christin 2012). The importance of trading on the Silk Road for the Bitcoin economy is further supported by more recent data disclosed in connection with the FBI seizure, suggesting that revenues worth a total of 9.5 million bitcoin has been collected through the site (Fernholz 2013). If Bitcoin eventually evolves into a fully functional currency with a mature base of users and if future historians are going to write the history of Bitcoin, it is not unlikely that they are going to point to the Silk Road as an important factor in kick starting the currency. Silk Road may turn out to have been the initial instigator of the desire for Bitcoin as money. 
A final reflection on the status of Bitcoin as a kind of post-fiat money is provided by the proposal of financial commentator, Max Keiser, that Palestine adopt the currency as an alternative to the Israeli Shekel, which is currently the official currency in the Palestinian Authorities of Gaza and the West Bank:

The Palestinian economy is a multi-billion dollar economy that unfortunately benefits mostly outsiders. But if Bitcoin were adopted as the official currency, Palestinians would be able to shape their own economic destiny and in so doing their sovereign destiny. In very short order, Palestine would have the soundest currency in the world, as coveted and as stable as gold and silver. As various paper 'fiat' money continues to get debased in countries around the world, Palestine's currency would maintain its purchasing power. The living standards of Palestinians would increase to the point where the Palestinian bitcoin currency would put the Israeli shekel to shame. (Keiser 2013)

Although the proposal is currently nothing but a loose idea that is nowhere near any actual implementation, it does open an interesting perspective on the way that Bitcoin throws our conventional conceptions of the relations between money and nation states into question. As we have seen, the fiat theory describes the way that money is a creation of the sovereign state. Now if Bitcoin were to be adopted by Palestine with the effects suggested in the above quote, we might see the process working in the opposite direction. By making the Palestinians 
independent from Israeli monetary policy, the post-fiat money of Bitcoin would function to create Palestinian sovereignty rather than the other way around.

\section{Credit Money without Debt}

The third and final ideal type of our analytical framework is constituted by the credit theory of money. This theory boils down to the simple statement that money is debt. A standard reference for this theory is Alfred Mitchell Innes, who says: 'Credit and credit alone is money' (1913, 393). And he provides the following elaboration:

Shortly, The Credit Theory is this: that a sale and purchase is the exchange of a commodity for credit. From this main theory springs the sub-theory that the value of credit or money does not depend on the value of any metal or metals, but on the right which the creditor acquires to "payment." $(1914,152)$

In other words, money is a claim on a debtor obligating the holder to receive payment in redemption of the debt. While all money is debt, the converse is not necessarily true. Not all debt is money. For debt to become money it must be able to circulate at a constant nominal value among the members of an economic community. The value of money as debt ultimately depends on the credit worthiness of the debtor. A $£ 1,000$ credit on a beggar does not hold the same value as a $£ 1,000$ credit on a billionaire. More recent formulations of the credit theory thus emphasize the crucial role of commercial banks in the creation of money (Werner 2005; Benes and Kumhof 2012; Jackson and Dyson 2013). Banks 
stand out as the ultimate or even sublime creditors in the economy, which means that their debts are accepted in payments at no discount from their nominal value. $£ 1,000$ in the bank buys exactly $£ 1,000$ worth of commodities at a store. When a commercial bank makes a loan of $£ 1,000$ it does not have to pay out the loan in cash, gold or some other form of money. In return for the loan, the bank simply credits the borrower's account and now this newly issued credit may itself function as money. Given the extensive electronic credit payment systems today, this credit money does not need to be converted into cash or central bank reserves in order to function as payment.

Our contemporary money system may be understood as a combination of two different kinds of money: 1) fiat money in the form of physical cash or central bank reserves held in the commercial banks' account with the central bank, and 2) credit money in the form of deposits in private money users' current accounts with the commercial banks (Ryan-Collins et al. 2011, 15-16). In this system, credit money functions as immediate means of payment as they circulate between different commercial bank customers. Central bank fiat money are only used to clear outstanding balances between the different banks in the system at the end of every bank day. Since most payments are automatically cleared throughout the day, when payments in opposite directions circulate between account holders in different commercial banks or even between different account holders in the same bank, commercial banks need to hold only a very small amount of central bank reserves relative to the amount of outstanding credit money in customers' deposit accounts. The difference between the two kinds of money is at the heart of the so- 
called fractional reserve banking, which allows private commercial banks to create new credit money as they lend this money to customers.

The paradox of fractional reserve banking is that on the one hand, commercial bank credit money circulate at the same value as state issued fiat money, while on the other hand the amount of outstanding credit money vastly exceed the amount of fiat money on reserve in the bank. We can understand the way that this system is maintained through Zizek's concept of ideology:

Ideology involves translating impossibility into a particular historical blockage, thereby sustaining the dream of ultimate fulfillment - a consummate encounter with the Thing. On the other hand ... ideology also functions as a way of regulating a certain distance with such an encounter. It sustains at the level of fantasy precisely what it seeks to avoid at the level of actuality. .... So ideology appears to involve both sustenance and avoidance in regard to encountering the Thing. (Žižek and Daly 2004, 70-71)

The ideology of fractional reserve banking 'translates' the structural 'impossibility' of all bank customers demanding their credit money paid out in state issued fiat money into a particular, practical matter of convenience. Each individual customer could in principle go down to the bank and have his deposits paid out in cash. And the bank makes sure to manage its holdings of liquidity to accommodate any customer wishing to do so. But precisely by offering this possibility, the bank prevents the majority of customers from ever doing so. By maintaining the fantasy among customers that they can convert their credit money 
into 'the real Thing' at any time, this ideology 'regulates a certain distance with such an encounter.' Since electronic credit money is typically much more convenient than fiat cash money, there is no reason for customers to convert their money. Convertibility of credit money into fiat money is 'sustained at the level of fantasy precisely to avoid it at the level of actuality.' Today we live in the age of post-credit money, where the vast majority of payments are nothing but the exchange of commercial bank credits between money users and these credits rarely come back for redemption in any other form of money than simply more commercial bank credit (Bjerg 2014, 155-192).

Since credit money is ultimately a contractual relation between a creditor and a debtor, the materiality of the money has very little significance. In fact, credit money is most often purely virtual as it is nothing but the recording of the relation between creditor and debtor in a book keeping system. We can easily recognize this feature in the case of Bitcoin. The core of Bitcoin is the block chain, which functions as a public ledger registering the credits of the money users in the system. The value of a particular Bitcoin wallet is the corresponding credit recorded in the block chain.

At the same time, there are of course also crucial differences between Bitcoin and conventional forms of credit money. Most importantly, Bitcoin creates new money denominated in its own currency. When ordinary commercial banks are allowed to issue new credit denominated in the national currency of the state, in which they are operating, they are in effect granted the license to issue the money supply of that state. This license means that commercial bank credit money 
circulate on par with actual physical cash printed by the central bank. When merchants accept money as payment for goods or services, they do not care much if the payment is made in electronic credit money or in physical cash. And ultimately even the state accepts bank credit money as payment for taxes, fines and other debts to the state. In brief, commercial bank credit money is sanctioned by fiat.

Bitcoins obviously differ from these conventional money created in the zone of indistinction between official government and private banking enterprise, since Bitcoin is not only a system for the creation of new money but even also an independent currency. When people hear about Bitcoin for the first time, they are often puzzled by the way that the system seems to create new money out of nothing. While there are indeed reasons to be puzzled about Bitcoin, it is perhaps even more curious that we readily accept the creation of new money out of nothing by the conventional commercial bank system. At least Bitcoin is not parasitic on the national currency of any sovereign state. If Bitcoin should eventually collapse in a spiral of hyperinflation, it is only going to affect those money users, who have voluntarily chosen to invest some of their money in Bitcoin. When sizeable commercial banks collapse, they tend to take with them their host organism, which is the whole currency of the state in which they are operating. This is of course why the hosting government often does not allow these parasites to fail.

Another difference between Bitcoin and conventional bank credit money is that new bitcoins are created and introduced into the economy free of debt. When 
commercial banks issue new credit that circulates as money, this is typically the other side of the customers' debt to the bank. Since the customer's debt to the bank is typically charged with a much higher interest rate than the bank's debt to the customer, there is an inherent tendency in this system for the total amount of debt to grow faster than the total supply of money (Binswanger 2013). As we have already touched upon, Bitcoin is similar to state issued fiat money in this respect. A bitcoin does not represent a claim on any particular debtor but rather a claim upon the whole 'society' of Bitcoin users. Bitcoin is credit money without debt.

It is not unlikely that in the future we are going to see credit institutions offering loans denominated in Bitcoin. Such institution are, however, necessarily going to differ from the way that commercial banks operate within the conventional money system. In the Bitcoin system, there is only one kind of money and payments are almost immediately cleared through the block chain. This means that a commercial bank wanting to lend Bitcoins to a customer would need to have this money in advance. It might borrow the money from another customer with a surplus of bitcoins or it might take it out of it's own reserves. The bank does not, however, have the power to create new bitcoins by simply crediting the borrower's deposit account with the bank.

\section{The Worst Form of Money}

[T]here is no seduction which is not in a way an incorrect intrusion or harassment. At some point you, if you are a seducer, you have to expose yourself to make a pass, as we usually put it. So does this 
mean that every seduction is all the way through an incorrect harassment? No, and therein resides the catch. When you make a pass, you expose yourself to the other, the potential partner, and she decides retroactively, by her reaction, whether what you just did was harassment or a successful act of seduction. And there is no way to tell in advance what her reaction will be. (Žižek 1999)

So what is Bitcoin: Is it the currency of the future, or is it merely just a Ponzi scheme for the internet age? Of course this is the question that everyone with any interest in Bitcoin is all curious to find out. But perhaps this is the wrong way of posing the question of Bitcoin. At least if we believe that we can deduce the answer from the structure and constitution of Bitcoin itself. As we have seen from the preceding analysis, there is no gold, state, or debt backing the value of Bitcoin. However, this should not lead us to the conclusion that Bitcoin is in some sense a fake form of money. Or at least, Bitcoin is no more fake than more conventional forms of money.

All forms of money come with their own forms of exploitation, risks and even violence. But once a certain form of money has become fully integrated into the general economic structure of society, we seem to accept these forms of exploitation, risks, and violence as something inevitable and even natural. Today we accept that governments hold the monopoly of printing money and demanding these back in payment of taxes from citizens. We also accept that commercial banks hold the privilege of circumventing this monopoly by issuing new electronic money, while at the same time charging customers interests for lending 
these newly created money. Taxes and interests seem to be an inevitable and natural part of the economic constitution of society. This is where Žižek's remark about seduction becomes pertinent. The act of seduction necessarily involves an element of intrusion and harassment. But if the seduction succeeds and the seduced party accepts the invitation to engage in a relation, this 'violent foundation' of the relationship is retroactively effaced and rewritten into a romantic story about 'love at first sight'. If, on the other hand, the seducer's first invitation is rejected and the seduction unsuccessful, he (the gender of the pronoun is not incidental) subsequently stands out as a 'sleazy pig' or even a potential rapist.

Bitcoin presently stands at a point, where it has made its first approach to the general economy. The response from users and merchants is largely still pending. It is to be decided whether the currency gains credibility and acceptance from a group of users and merchants big enough for it to build momentum and rise above its current status as a monetary curiosity and a speculative asset. Furthermore, it also remains to be seen whether current monetary monopoly holders such as governments and established banking institutions are going to embrace Bitcoin as a new technology to further their existing strategic goals or regard it as a disruptive competitor that must be thwarted. If history turns out to be on the side of Bitcoin and if the currency is generally accepted and integrated into our system of economic transactions, the nature of Bitcoin is retroactively going to be determined along the lines of being an ingenious, efficient, cheap, democratic, and ultimately stable system of money. The role of the Silk Road in the initial 
stage of Bitcoin's evolution will be recorded as nothing but a curiosity and the fact that early adopters will have profited immensely from the success of the system is going to be seen as a fair reward for their economic foresight. But if Bitcoin fails to gain general recognition and acceptance, the currency is going to go down in history as nothing but a digital Ponzi scheme. Returning to the analogy of seduction, Satoshi Nakamoto is going to stand out as a sleazy pig and a financial rapist.

Of course Bitcoin should not be embraced without any kind of scepticism. It is true, as suggested by central banks and other financial authorities that have come out to warn against Bitcoin, that users are at risk of losing their money if the currency suddenly devalues. It is also true when critics point out that the currency can be used for illicit purposes such as drug dealing, tax evasion and money laundering. And finally, it is also true that early adopters are seeing windfall speculative profits as the price of Bitcoin multiplies with the increase of new users thus potentially creating a 'Bitcoin aristocracy' (Kostakis and Giotitsas 2014, 437; Kostakis and Bauwens 2014, 33). What is interesting about all of these points of criticism, however, is that they apply equally and perhaps even more pertinently to our current forms of conventional money: If the US dollar loses its status as world reserve currency, its value is likely to drop dramatically and a lot of people are going to lose a lot of money (eg. Rickards 2014). In this respect, there is essentially no difference between Bitcoin and the US dollar or any other national currency for that matter. Furthermore, neither drug dealing, tax evasion, nor money laundering has come into being with the advent of Bitcoin. All of these 
deplorable activities were already working fine with conventional cash money or even bank credit money transferred to off-shore accounts in Jersey, Bahamas or another international tax haven before anyone had thought of Bitcoin or the Silk Road (eg. Shaxson 2011). And finally, it is hardly controversial to suggest that our existing system of money, banking and finance already contains elements of a Ponzi scheme with a small minority of agents and institutions favorably placed to take profitable advantage of the rest of the people in the system (eg. Mallaby 2011). These critiques almost resembles a form of Freudian projection, where the deficiencies of conventional money are ascribed to Bitcoin. Our analysis of Bitcoin may thus be summarized by a paraphrase of Winston Churchill's famous remark about democracy: 'Bitcoin is the worst form of money, except for all the others.' 
Literature

Ali, Robleh, John Barrdear, Roger Clews, and James Southgate. 2014. "The Economics of Digital Currencies." Bank of England Quarterly Bulletin, Q3.

Barber, Simon, Xavier Boyen, Elaine Shi, and Ersin Uzun. 2012. "Bitter to Better — How to Make Bitcoin a Better Currency.” In Financial Cryptography and Data Security, edited by Angelos D. Keromytis, 399-414. Berlin: Springer.

Barratt, Monica J. 2012. "Silk Road: eBay for Drugs.” Addiction 107 (3): 683683.

Bell, Stephanie. 2000. "Do Taxes and Bonds Finance Government Spending?" Journal of Economic Issues 34 (3): 603-20.

Benes, Jaromir, and Michael Kumhof. 2012. The Chicago Plan Revisited. IMF: IMF Working Paper, 12/202.

Binswanger, Hans Christoph. 2013. Die Wachstumsspirale: Geld, Energie und Imagination in der Dynamik des Marktprozesses. Marburg: MetropolisVerlag.

Bjerg, Ole. 2014. Making Money - The Philosophy of Crisis Capitalism. London: Verso.

Bryan, Dick, and Michael Rafferty. 2006. "Financial Derivatives: The New Gold?" Competition \& Change 10 (3): 265-82.

_ 2007. "Financial Derivatives and the Theory of Money." Economy and Society 36 (1): 134-58. 
—. 2009. "Homemade Financial Crisis." Ephemera: Theory \& Politics in Organization 9 (4): 357-62.

—. 2012. "Why We Need to Understand Derivatives in Relation to Money: A Reply to Tony Norfield.” Historical Materialism 20 (3): 97-109.

Christensen, Neils. 2013. “2013: Year Of The Bitcoin.” Forbes. www.forbes.com. Christin, Nicolas. 2012. "Traveling the Silk Road: A Measurement Analysis of a Large Anonymous Online Marketplace.” arXiv:1207.7139, July.

Dodd, Nigel. 2014. The Social Life of Money. New Jersey: Princeton University Press.

Fernholz, Tim. 2013. "Silk Road Collected 9.5 Million Bitcoin—and Only 11.75 Million Exist.” Quartz. www.qz.com.

Graeber, David. 2011. Debt: The First 5,000 Years. New York: Melville House.

Greenberg, Andy. 2013. “'Silk Road 2.0’ Launches, Promising A Resurrected Black Market For The Dark Web.” Forbes. www.forbes.com.

Hayek, F. A. 1976. Denationalisation of Money: The Argument Refined. London: London Publishing Partnership.

Heidegger, Martin. 1927. Sein Und Zeit. Tübingen: Max Niemeyer Verlag.

Hudson, Michael. 2004. "The Archaeology of Money: Debt Versus Barter Theories of Money's Origins." In Credit and State Theories of Money: The Contributions of A. Mitchell Innes, edited by L. Randall Wray, 99127. Cheltenham: Edward Elgar Publishing. 
_ 2012. The Bubble and Beyond. Dresden: Islet.

Humphrey, Caroline. 1985. "Barter and Economic Disintegration." Man 20 (1): $48-72$.

Ingham, Geoffrey. 2000. “'Babylonian Madness': On the Historical and Sociological Origins of Money." In What Is Money, edited by John Smithin, 16-41. London: Routledge.

- 2004. The Nature of Money. Cambridge: Polity.

— 2006. "Further Reflections on the Ontology of Money: Responses to Lapavitsas and Dodd." Economy and Society 35 (02): 259-78.

Innes, A. Mitchell. 1913. "What Is Money." The Banking Law Journal 30: 377.

—. 1914. "Credit Theory of Money." The Banking Law Journal 31: 151.

Jackson, Andrew, and Ben Dyson. 2013. Modernising Money: Why Our Monetary System Is Broken and How It Can Be Fixed. London: PositiveMoney.

Karlstrøm, Henrik. 2014. "Do Libertarians Dream of Electric Coins? The Material Embeddedness of Bitcoin.” Distinktion: Scandinavian Journal of Social Theory 15(1): 23-46.

Keen, Steve. 2011. Debunking Economics: The Naked Emperor Dethroned. London: Zed.

Keiser, Max. 2013. "Should Palestine Switch from the Shekel to Bitcoin?" $R T$. WwW.rt.com.

Keynes, John Maynard. 1936. The General Theory of Employment, Interest, and Money. New York: Harcourt. 
Knapp, Georg Friedrich. 1924. The State Theory of Money. London: Macmillan and Company.

Kostakis, Vasilis, and Michel Bauwens. 2014. Network Society and Future Scenarios for a Collaborative Economy. Palgrave Macmillan.

Kostakis, Vasilis, and Chris Giotitsas. 2014. "The (A)Political Economy of Bitcoin.” tripleC: Communication, Capitalism \& Critique 12 (2): 431-40.

Lacan, Jacques. 1966. "The Function and Field of Speech and Language in Psychoanalysis.” In Ecrits. London: W. W. Norton \& Company.

Luther, William J. 2013. Cryptocurrencies, Network Effects, and Switching Costs. SSRN Scholarly Paper ID 2295134. Rochester, NY: Social Science Research Network.

Luther, William J., and Lawrence H. White. 2014. Can Bitcoin Become a Major Currency?. Working Paper ID 2446604. Rochester, NY: Social Science Research Network.

Mallaby, Sebastian. 2011. More Money Than God: Hedge Funds and the Making of a New Elite. New York: Penguin.

Maurer, Bill, Taylor C. Nelms, and Lana Swartz. 2013. “"When Perhaps the Real Problem Is Money Itself!': The Practical Materiality of Bitcoin.” Social Semiotics 23 (2): 261-77.

Meiklejohn, Sarah, Marjori Pomarole, Grant Jordan, Kirill Levchenko, Damon McCoy, Geoffrey M. Voelker, and Stefan Savage. 2013. "A Fistful of Bitcoins: Characterizing Payments Among Men with No Names." In 
Proceedings of the 2013 Conference on Internet Measurement Conference, 127-40. IMC '13. New York: ACM.

Menger, Karl. 1892. “On the Origin of Money.” The Economic Journal 2 (6): $239-55$.

Mosler, Warren. 1997. "Full Employment and Price Stability." Journal of Post Keynesian Economics 20 (2): 167-82.

Nakamoto, Satoshi. 2008. "Bitcoin: A Peer-to-Peer Electronic Cash System." www.bitcoin.org.

Rickards, James. 2014. The Death of Money: The Coming Collapse of the International Monetary System. New York: Portfolio Penguin.

Rosenblum, Paula. 2014. "Bitcoin: The Currency Of The Future?" Forbes. www.forbes.com.

Ryan-Collins, Josh, Tony Greenham, Richard Werner, and Andrew Jackson. 2011. Where Does Money Come From? - A Guide to the UK Monetary and Banking System. London: New Economics Foundation.

Selgin, George. 2014. "Synthetic Commodity Money." Journal of Financial Stability (in press).

Shaxson, Nicholas. 2011. Treasure Islands: Uncovering the Damage of Offshore Banking and Tax Havens. London: Palgrave Macmillan.

Simmel, Georg. 1900. The Philosophy of Money. London: Routledge.

Smith, Adam. 1776. The Wealth of Nations. New York: The Modern Library.

Trugman, Jonathon M. 2014. "Welcome to 21st-Century Ponzi Scheme: Bitcoin." New York Post. February 15. www.nypost.com. 
Werner, Richard. 2005. New Paradigm in Macroeconomics: Solving the Riddle of Japanese Macroeconomic Performance. Basingstoke: Palgrave Macmillan. Wray, L. Randall. 1998. Understanding Modern Money: The Key to Full Employment and Price Stability. Cheltenham: Edward Elgar Publishing.

Žižek, Slavoj. 1989. The Sublime Object of Ideology. London: Verso. 1999. "Human Rights and Its Discontents." Lecture at the Bard College 15: 1999.

. 2006. How to Read Lacan. London: W. W. Norton \& Company.

Žižek, Slavoj, and Glyn Daly. 2004. Conversations with Žižek. Cambridge: Polity.

i This analytics of money is more thoroughly developed in Making Money - The Philosophy of Crisis Capitalism (Bjerg 2014). 